\title{
Plant biodiversity and vegetation structure in traditional cocoa forest gardens in southern Cameroon under different management
}

\author{
Bisseleua D. Hervé B. · Stefan Vidal
}

Received: 20 April 2007/Accepted: 23 October 2007/Published online: 20 November 2007

(C) Springer Science+Business Media B.V. 2007

\begin{abstract}
Floristic surveys were performed in 17 traditional cocoa forest gardens under different management regimes in the humid forest area of southern Cameroon, to assess the impact of intensification on plant biodiversity. This impact was evaluated by analyzing species richness, vegetation structure, carbon sequestration and above ground biomass. We hypothesize that: (a) plant (tree and herbs) species richness is negatively correlated to management intensity and (b) vegetational density predictably change with management intensity. Our results show that management as practiced in traditional cocoa forest gardens in southern Cameroon following a gradient of intensification from extensive cocoa forest gardens with high floristic diversity to intensive ones strongly impacts plant diversity, plant biomass and to some extend carbon storage with possible negative consequences on biodiversity. Great differences in species richness, species composition, and, for trees, diameter at breast height and basal area were evident among the five types of traditional cocoa forest garden systems investigated. In terms of plant species richness, we found a decreasing gradient of plant species numbers from extensive forest gardens to intensive ones. This study also highlights the importance of the Management Index for quantifying differences in the management; this index could be used to standardize certification procedures and assess conservation progress and success. Our findings support the idea that traditional cocoa forest gardens can help to protect many forest species, sustains smallholder production and offer more scope for conservation of biodiversity, at both species-level and landscape-level. Moreover, diverse traditional cocoa forest gardens may help in regulating pests and diseases and allow for efficient adaptation to changing socioeconomic conditions.
\end{abstract}

Keywords Agroecology · Biodiversity conservation · Cocoa agroforest · Intensification $\cdot$ Management index $\cdot$ Management regime $\cdot$ Southern Cameroon

Bisseleua D. Hervé B. $(\bowtie) \cdot S$. Vidal

Department of Crop Science, Entomological Section, Georg-August-University Goettingen, Grisebachstr. 6, Goettingen, Germany

e-mail: hbissel@gwdg.de

Bisseleua D. Hervé B.

Institute of Agricultural Research for Development (IRAD), Nkolbisson Regional Research Centre, BP 2067 Yaounde, Cameroon 


\section{Introduction}

Agroforestry involves either the incorporation of trees in agricultural cropping systems or the incorporation of crops in forest systems. Traditionally, agroforestry research has focused on the first development pathway (the incorporation of trees in agricultural cropping systems) with less attention on multi-strata cropping systems that mimic the structure of natural forests (Lefroy et al. 1999; Muschler and Beer 2001). In southern Cameroon the structure of the landscape is characterized by natural rainforest, forest gardens (mixed tree plantations surrounding or at some distance from villages, usually less intensively tended than homegardens and they include a higher percentage of native trees (Wiersum 2004), homegardens and annual field crops (Degrande and Duguma 2000). Several research projects have focused on homegardens with little attention to other types of agroforests such as traditional forest gardens (TFGs) (Guyer 1984; Ruf and Schroth 2004). It is only since several years that these "intermediate" management systems (Michon and De Foresta 1997) are gradually receiving increasing interest (Laird et al. 2007; Sonwa et al. 2007). In such systems tree composition is adapted to local needs, and their structure is close to that of natural forests. Their management practices are influenced by their relationship to the other components of the land-use system and are oriented at using a combination of multiple forest resources (Sonwa et al. 2001; Schroth et al. 2004; Perfecto et al. 2005). Their adaptive nature offers options for combining biodiversity conservation and production for human benefits (Greenberg et al. 2000; Reitsma et al. 2001; Perfecto et al. 2004; MCNeely and Schroth 2006; Gordon et al. 2007; Steffan-Dewenter et al. 2007). TFGs are developed as a result of the interactions between local communities and forests and reflect various forms of human creativity in dealing with forest resources. They could be regarded as a mixture of natural forest tree species such as fruit tree species, timber species, semi-cultivated woody plants (Elaeis guineensis) and cultivated plants (cocoa and bananas), presenting a high level of plant diversity, and potentially be of high conservation value (Zapfack et al. 2002; Bobo et al. 2006; Merijn et al. 2007; Sonwa et al. 2007). They form a dynamic component of an integrated local land-use system, providing supplementary products such as fruits, cash crops, firewood and/or medicines. Moreover, TFGs provide opportunities in developing new approaches in conservation of tropical rainforests and biodiversity, as well as increased recognition of indigenous land-use systems as a possible way for sustainable development (Gordon et al. 2007; Steffan-Dewenter et al. 2007).

This paper aims to demonstrate the impact of management intensity on plant diversity and vegetation structure of TFGs in southern Cameroon. This impact can be evaluated by analyzing species richness, vegetation structure, carbon sequestration and above ground biomass. We hypothesize that: (a) plant (tree and herbs) species richness and management intensity are negatively related (b) vegetational density predictably change with management intensity.

\section{Methods}

Study sites

Our surveys were conducted in the semi-deciduous rainforest region in five major cocoagrowing regions within 17 cocoa farms in southern Cameroon. The study areas are 
located between $2^{\circ} 35^{\prime} \mathrm{N}$ and $4^{\circ} 15^{\prime} \mathrm{N}$ and $11^{\circ} 48^{\prime}$ and $11^{\circ} 15^{\prime} \mathrm{E}$. The altitude varies between 450 and $715 \mathrm{~m}$ above sea level and is characterized by a subequatorial climate, with a bimodal rainfall regime. The mean annual temperature is around $25^{\circ} \mathrm{C}$ with a relatively small thermal variation. The mean annual rainfall is around $1,900 \mathrm{~mm}$. The soils are Oxisols/Ultisols, which make up about $80 \%$ of the soils in the humid forest region of Cameroon and the $\mathrm{pH}$ of the soil varies from 4.29 to 5.43 (Kotto-Same et al. 1997; Kanmegne et al. 2006).

The five regions may be characterized as follows: (1) Ngomedzap is in the south around the Mbalmayo forest reserve, which is partially logged due to a low-population density with old cocoa forest gardens ( $\sim 50$ years and more) near the forest margin or in the dense forest; (2) Obala in the center, with no original forests remaining because of very high human population density and relatively old cocoa forest gardens ( $\sim 40$ years and more), located in strongly degraded semi-deciduous forest near houses and villages; (3) Bakoa and (4) Kedia in the northern extreme west with old ( $\sim 30$ years and more) and young $(\sim 8-$ 15 years) cocoa forest gardens, respectively, in forest galleries at the forest-savannah transition zones; and (5) Talba in the northern extreme east with mature cocoa forest gardens ( $\sim 15-20$ years) in or near the forest. The Ngomedzap area is considered by cocoa farmers to be less technified (more dense and diverse shade, fewer chemical inputs) and could be compared to the "rustic" cocoa areas (Greenberg et al. 2000) reported in Latin America. The Kedia and Talba areas are considered to be more technified (less dense and diverse shade, high-chemical inputs) and are seen as the pioneer front in cocoa cultivation in southern Cameroon.

Five Union of GICs (Common Initiative Group) and four federations of cocoa farmers within the five regions were identified and selected for the study, regrouping 41 GIC with a total of 2,597 cocoa farmers. In each region, the process started with a community meeting with the help of ASPA (Appui aux Stratégies Paysannes et à la Professionnalisation de l'Agriculture) of the Ministry of Agriculture and Rural Development (MINADER) to inform all cocoa farmers and the respective "Common Initiative Group" (GIC) about the objectives of the study and to ask for their participation and action planning. During the pilot phase, 20 cocoa farms were inspected per union. We selected the farms according to a land-use intensity gradient based on density, plant diversity, height of shade trees, percent of shade and herb cover and the age of cocoa trees (Philpott et al. 2006). The selected farms represented individual land holdings. Ngomedzap was considered as an extensively managed old traditional cocoa forest garden (EO), Bakoa as an extensively managed young traditional cocoa forest garden (EY), and Obala as a home garden cocoa forest (HG), because all plantations are located very close to the houses in the village. Talba was considered to be an intensively managed mature traditional cocoa forest gardens (IM) and Kedia as an intensively managed young traditional cocoa forest gardens (IY). The management practices in Bakoa were similar to that of Ngomedzap, but with less dense and diverse shade and moderate chemical inputs. Farmers in Bakoa claimed to have trained those of Talba in proper management of their cocoa plantations that resulted in their higher production. The rate of pesticides application, insecticides applied, the main used of plant species and intentionally introduced tree species were assessed through individual interviews with selected farmers. In all our study sites cocoa production was the main cash crop, occupied most of the landscape and accounted for more than half of the total cocoa production in southern Cameroon, with $28 \%$ of the total production of the whole country (Annon 2002). 
Plant survey and estimation of tree biomass

The ecological survey was performed between July and December 2005 in five cocoa growing regions in the humid forest area of southern Cameroon, which include both evergreen and deciduous rainforest. We selected 17 cocoa plantations (sites) within five types of traditional cocoa forest gardens (TFGs) namely EO, EY, HG, IM, and IY as follows: two EO (Ngomedzap), four EY (Bakoa), IM (Talba), and IY (Kedia), respectively, and three HG (Obala). Vegetation characteristics were determined within $600 \mathrm{~m}^{2}$ plots $(20 \times 30 \mathrm{~m})$ in each site. For each site, all non-cocoa trees with diameter at breast height $(\mathrm{dbh}) \geq 10 \mathrm{~cm}$ were individually counted, numbered, identified and their density per plot estimated. Their crown class, dbh, as well as their full height was measured and the basal area (BA) was calculated. The BA per quadrate $\left(600 \mathrm{~m}^{2}\right)$ was calculated as follows: BA $\left(\mathrm{m}^{2} / \mathrm{ha}\right)=\Sigma 0.00007854 \mathrm{D}^{2}$, where $\mathrm{D}$ is the dbh per tree. The BA is included to give a rough approximation of plant biomass production, which usually increases with age (Carrière et al. 2002). The above ground tree biomass was calculated using the equation $\ln B=-3.375+0.948 \times \ln \left(D^{2} \times H\right)($ Steffan-Dewenter et al. 2007), where $B$ is the aboveground biomass, $D$ is the dbh, and $H$ is the total tree height, respectively.

Herb species were sampled and counted in 15 quadrates of $2 \times 1 \mathrm{~m}^{2}$ in each plot per TFG. Scientific and vernacular names (the latter given by local cocoa farmers and local traditional practitioners) were recorded. The uses of each species (nutritive, timber, medicinal plants, fertilizers, etc.) were also determined. Species that could not be identified in the field were collected, pressed in between newspaper for later identification at the National Herbarium of Cameroon (Yaoundé). Also, within each site, cocoa tree parameters (i.e., spacing between cocoa trees, tree density, cocoa tree height, girth, crown depth and width, height of branching, and the number of chupons per tree, respectively) were monitored to assess management practices. These 17 study sites had a minimum size of 1 ha and a minimum distance to the nearest neighbor of $500 \mathrm{~m}$. Sampling was standardized and performed on a spatial unit size comparable to typical management unit to avoid correction of richness data by rarefaction or through estimators. Diurnal temperature $\left({ }^{\circ} \mathrm{C}\right)$ and relative humidity $(\%)$ were measured under standardized conditions (sunny days, 8-10 a.m.) in each plot. A combine Electronic hand-held hygro-thermometer (TECPEL CO LTD, Taiwan: Model DTM 321_ DTM 322) was used to measure temperature and relative humidity while daily rainfall was measured using a plastic pluviometer (Littoclime S.A, France). Canopy cover was measured at ten points per site using a hand-held spherical densiometer (R.E. Lemmon Forest Densiometers, USA) to estimate shading intensity.

A management index (MI) (Mas and Dietsch 2003; Philpott et al. 2006) was used to summarize vegetation variables per site in each region whereby all variables subjected to be affected by management were converted to a scale from 0 to 1 and then summed. We divided values for each variable in each site by the highest overall value, and then subtracted this from 1. All values were summed for a total possible of 7 (since seven vegetative variables were included in the index), where 7 is most and 0 is least-intensively managed site.

Diversity indices and statistical analysis

The number of species $S$ (species richness) (Samways 1984; Krebs 1989), the Shannon index of diversity $H^{\prime}$ (Colwell and Huston 1991), the Berger-Parker index of dominance $d$ 
(Magurran 1988), and index of evenness $E$ (Shannon and Weaver 1949) were selected to examine $\alpha$-diversity within all sites and habitat (TFG). We also used the Jaccard index (1) of plant similarity to examine $\beta$-diversity among the habitats.

$$
J_{\mathrm{I}}=S_{\mathrm{ij}} /\left(S_{\mathrm{i}}+S_{\mathrm{j}}-S_{\mathrm{ij}}\right),
$$

where $S_{\mathrm{ij}}=$ shared species; $S_{\mathrm{i}}=$ richness in first site; and $S_{\mathrm{j}}=$ richness in second site.

Data were analyzed using either Systat 11 or SPSS Version 11.0 (SPSS Inc. 2004).

When necessary, logarithm, arcsine-square or square root-transformed variables were used to achieve normal distribution. We analyzed diversity data by comparing measures of $\alpha$-diversity per site to estimate heterogeneity. A two-factor (sites, habitats) unbalanced nested design was used for an ANOVA on each of the dependent variables $(S, H, d$, and $E)$. The unbalanced design was necessary as a result of different numbers of sites for each habitat type. Diversity was compared within sites and sites nested within habitats. When the model found statistically significant differences in habitats and sites, Tukey's post hoc tests were used to determine which were significantly different. Data on species richness were analyzed by simple polynomial regression against canopy, aboveground biomass and herbaceous cover, respectively.

\section{Results}

General description

A total of 102 non-cocoa (companion) tree species and 260 herbaceous species were identified within the five traditional cocoa forest gardens. Species sampled belonged to 169 plant families; 56 families of trees, and 113 families of the herbs. The richest families were Moraceae (11 species) and Mimosaceae (6) in trees and the Acanthaceae (23 species), Commelinaceae (12), Poaceae (10), Araceae (8), Rubiaceae (6), and Asteraceae (4) in the herbs. There was a significant difference $(p<0.01)$ in the average number of tree $(F=7.30, d f=4)$ and herbaceous $(F=15.97, d f=4)$ families observed per TFG with HG recording the highest number of families from both plant groups and IM the lowest (Table 1). The most common tree species were Albizia adianthifolia and Ficus exasperata (17\% of the total species, respectively) followed by Ficus mucuso and Discoglypremna caloneura $(11 \%)$ in EO; Ceiba pentandra in IY; F. exasperata and Newbouldia lewis in EY; Terminalia superba in IM and Pterocarpus soyauxii in HG. Most of them were intentionally introduced as shade trees specifically in EY and IY.

Herbaceous species were dominated by Nephrolepis bisserata (Nephrolepideae) in EO; Chromolaema odorata, Oplismenus hirtellus, Laportia avalifolia, and Commelina sp in IY; O. hirtellus, L. ovalifolia, and Dicliptera verticillata in EY; Commelina sp, Acanthus montanus, Cythula prostata, Desmodium abscendens, and L. ovalifolia in IM and Psychotria sp and $O$. hiertellus in HG. All the herb species sampled depend on the period of the year because weeding is practiced throughout the cropping season.

Floristic diversity and habitat description

The plant species richness, Shannon-Weaver index, Shannon evenness and the BergerParker index of dominance for each TFG are presented in Table 1. A significant difference 


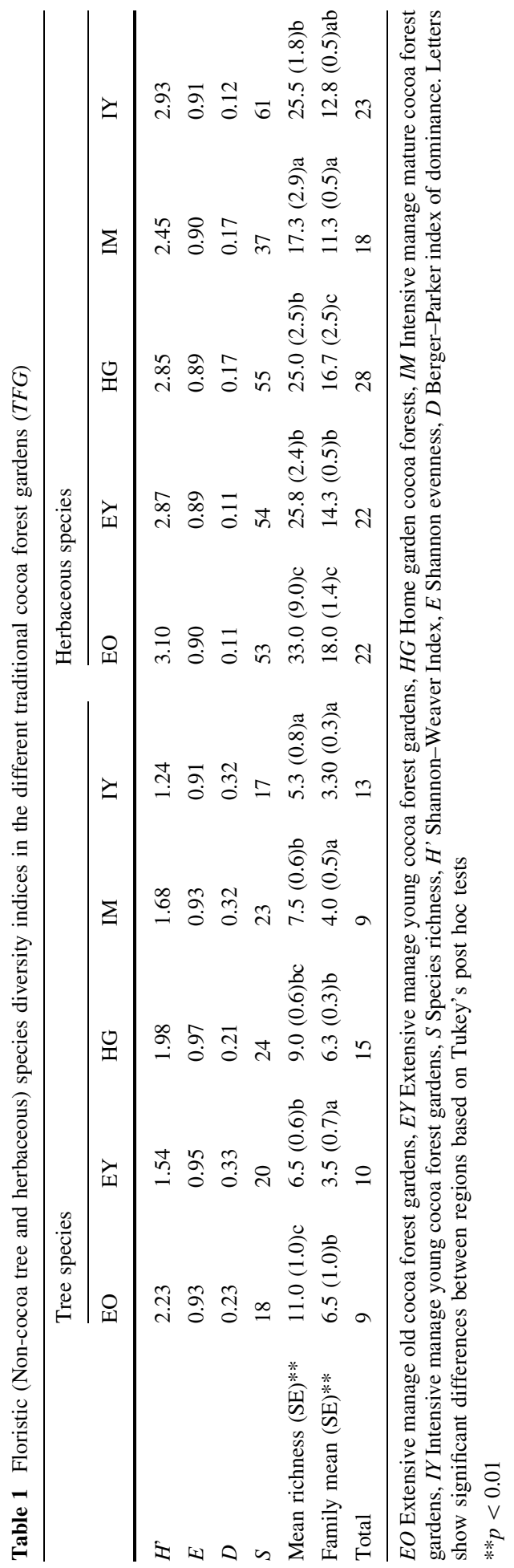


$(p<0.01)$ was observed between TFGs when analyzing tree species and herbaceous species richness, respectively. The average tree species richness was twofold higher in EO (11.0) as compared to IY (5.3). IM recorded the lowest herbaceous species richness and herbaceous cover. The Shannon-Weaver index between TFGs ranged from 1.54 to 2.23 for tree species and from 2.45 to 3.10 for herbaceous species. A significant difference was observed between TFGs for both two variables. Nevertheless, EO was the most diverse TFGs when considering the plant diversity indices (Table 1).

When taking into consideration the Jaccard Index (JI), the floristic similarity between TFGs decreased with increasing intensification (Table 2). Therefore, $\beta$-diversity was lower between sites under different land-use management. However, the highest similarity in floristic composition occurred between EY and IY.

When looking at the management practices in different TFGs, we observed that spacing between cocoa trees varied from $1.3 \mathrm{~m}(\mathrm{SE}=0.1)$ in $\mathrm{HG}$ to $2.1 \mathrm{~m}(\mathrm{SE}=0.0)$ in $\mathrm{IM}$ (Table 3). Spacing significantly differed $(p<0.01)$ between TFGs. The average cocoa tree height ranged from $6.4 \mathrm{~m}(\mathrm{SE}=0.0)$ in $\mathrm{EO}$ to $8.6 \mathrm{~m}(\mathrm{SE}=0.5)$ in IM. Tree height did not show any significant difference between TFGs as did tree girth, crown width and height at branching. However, a significant difference $(p<0.01)$ was observed between TFGs on crown depth of cocoa trees and the mean number of chupons per cocoa tree. This value ranged from $0.1(\mathrm{SE}=0.0)$ in $\mathrm{EO}$ to $0.9(\mathrm{SE}=0.2)$ in $\mathrm{HG}$ while crown depth ranged from $2.6 \mathrm{~m}(\mathrm{SE}=0.3)$ in $\mathrm{EO}$ to $5.7 \mathrm{~m}(\mathrm{SE}=1.0)$ in HG. There was a significant difference $(p<0.01)$ in cocoa tree density between TFGs with HG having the highest density and IM the lowest with 1,075 tree/ha (Table 3). The rate of pesticides application per cropping season significantly differed $(p<0.001)$ between TFGs with the extensive cacao production systems having fewer pesticide applications as compared to the intensive ones (Fig. 1). Insecticide application was found to be significantly different $(F=17.21, d f=4$, $p<0.001$ ) between TFGs with EO applying less insecticides (Fig. 1). Of the insecticides applied $43 \%$ were Organochlorine, 20\% Carbamate, 17\% organophosphate, $14 \%$ nicotinoid, and $4 \%$ pyrethroids.

\section{Vegetation structure}

Based on a one-way-ANOVA, density of non-cocoa tree significantly differed $(p<0.001)$ among TFGs with the density recorded in EO twofold higher than that observed in IY

Table 2 Percent similarity in non-cocoa (companion) trees species for all traditional cocoa forest gardens $(T F G)$

\begin{tabular}{|c|c|c|c|c|c|}
\hline \multirow[b]{2}{*}{ TFG } & \multicolumn{5}{|c|}{ Non-cocoa tree species } \\
\hline & $\mathrm{EO}$ & EY & $\mathrm{HG}$ & IM & IY \\
\hline $\mathrm{EO}$ & & 17 & 12 & 11 & 12 \\
\hline EY & & & 12 & 15 & 33 \\
\hline HG & & & & 14 & 15 \\
\hline \multirow[t]{2}{*}{ IM } & & & & & 19 \\
\hline & Herl & speci & & & \\
\hline EO & & 34 & 27 & 10 & 16 \\
\hline EY & & & 28 & 25 & 28 \\
\hline HG & & & & 17 & 16 \\
\hline IM & & & & & 25 \\
\hline
\end{tabular}




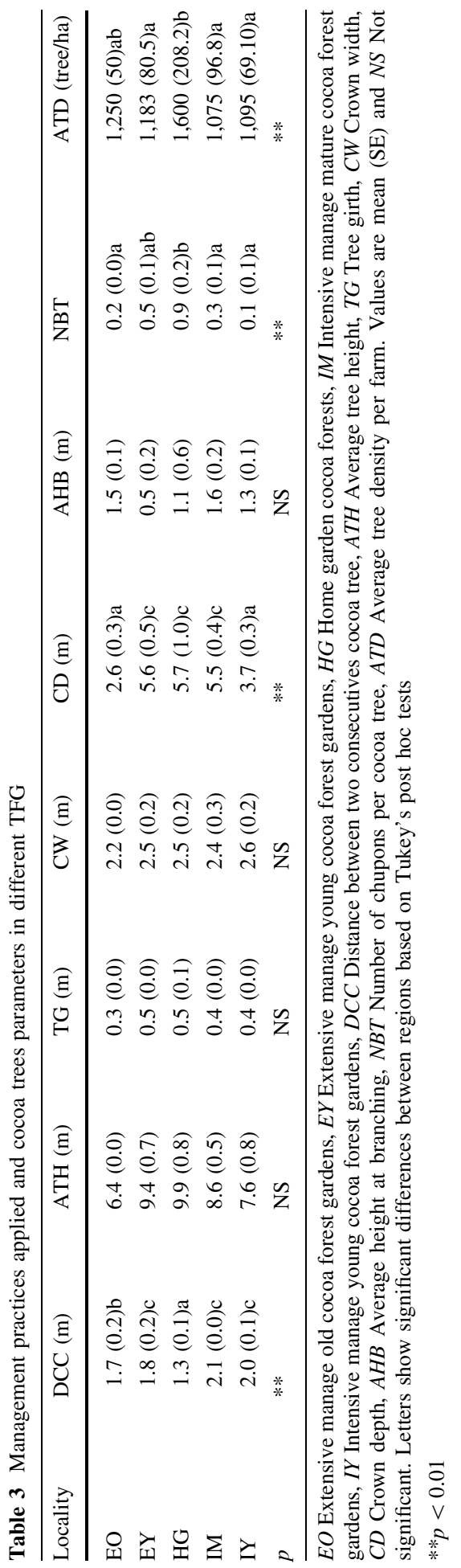


Fig. 1 Rate of Insecticides application in different traditional cocoa forest gardens $(F=17.21$, $d f=4, n=17)$

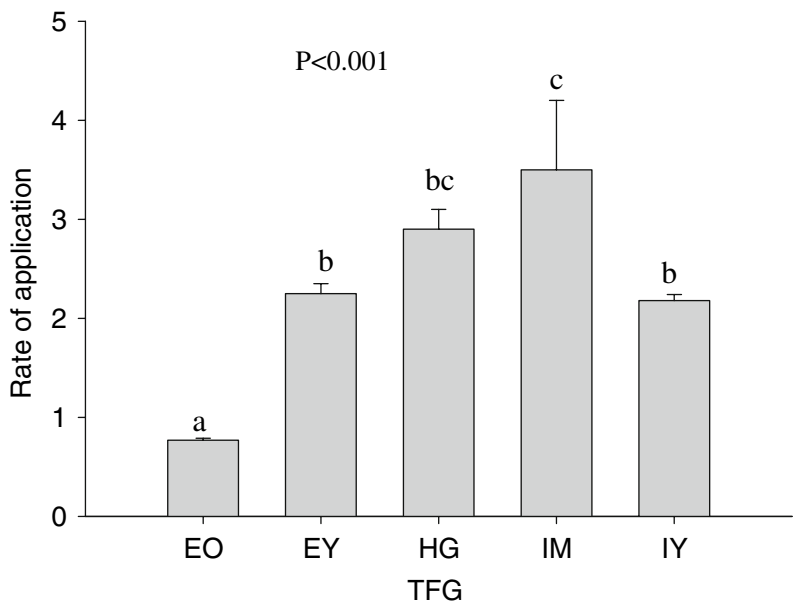

(Fig. 2). Dbh and tree height of non-cocoa trees in TFGs are summarized in Fig. 3. Both parameters significantly varied $(p<0.001)$ between TFGs. Mean dbh ranged from $62.25 \mathrm{~cm}(\mathrm{SE}=2.90)$ in $\mathrm{EO}$ to $135.85(\mathrm{SE}=13.46)$ in $\mathrm{IM}$. Mean dbh was $93.49 \mathrm{~cm}$ $(\mathrm{SE}=1.47)$ in $\mathrm{EY}, 124.42 \mathrm{~cm}(\mathrm{SE}=10.91)$ in $\mathrm{HG}$ and $115.97 \mathrm{~cm}(\mathrm{SE}=5.86)$ in $\mathrm{IY}$. Average height value of non-cocoa was higher in older systems than in younger ones. This value was $43.90 \mathrm{~m}(\mathrm{SE}=3.35)$ in $\mathrm{EY}, 44.16 \mathrm{~m}(\mathrm{SE}=1.51)$ in $\mathrm{IY} ; 55.50 \mathrm{~m}(\mathrm{SE}=3.26)$ in $\mathrm{EO}, 64.04 \mathrm{~m}(\mathrm{SE}=3.61)$ in $\mathrm{HG}$ and $65.64 \mathrm{~m}(\mathrm{SE}=2.91)$ in IM. Finally, we found a weak, although non-significant relationship between dbh and tree height.

Basal area (BA) and biomass production

Management had a significant $(p<0.001)$ effect on BA with IY recording the lowest BA $\left(9.5 \mathrm{~m}^{2} / \mathrm{ha}\right)$. IM recorded the highest BA-value $\left(46.7 \mathrm{~m}^{2} / \mathrm{ha}\right)$. Mean BA in HG was about

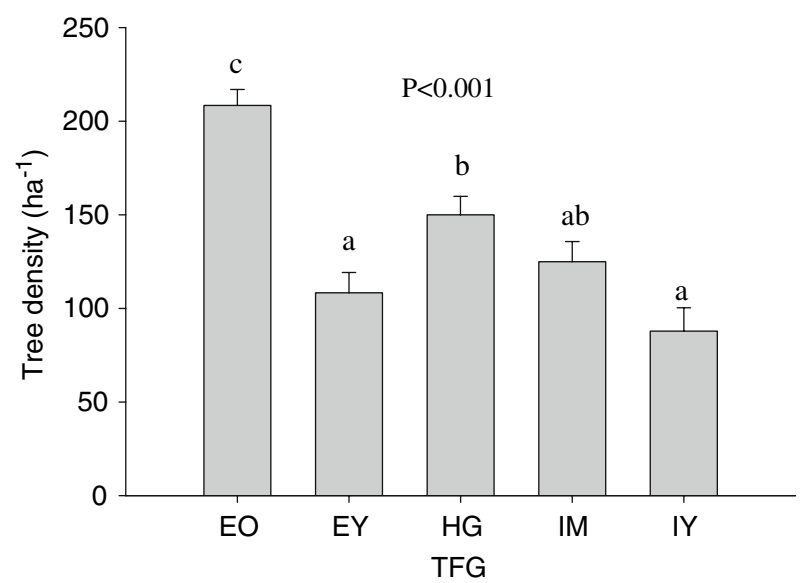

Fig. 2 Average tree density $\left(\mathrm{ha}^{-1}\right)$ in different traditional cocoa forest gardens 

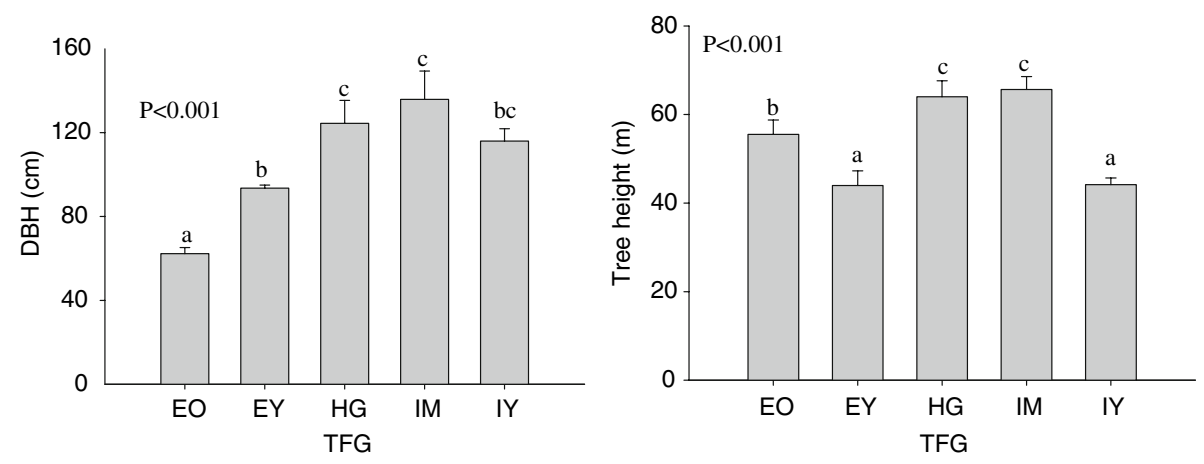

Fig. 3 Diameter at breast height $(\mathrm{cm})$ and tree height $(\mathrm{m})$ of non-cocoa trees in five land-use systems of traditional cocoa forest gardens in southern Cameron

twofold that of EY (Fig. 4). Standing tree biomass significantly $(p<0.001)$ decreased with intensification, with IY recording fourfold lower trees biomass than IM and EO, respectively. IM recorded the highest mean biomass per standing tree species with $374 \mathrm{~kg} /$ tree (Fig. 4). We observed a positive relationship between standing non-cocoa tree biomass and canopy cover $\left(R^{2}=0.37, p<0.05\right)$. We also found a positive relationship between standing non-cocoa tree biomass and tree species richness, however this relationship was not statistically significant.

\section{Ethnobotany}

Farmers normally preserve either medicinal species, fertilizers, nutritive and/or timber species in their TFGs. Many non-timber forest products were observed in the TFGs analyzed. These included the Sterculiaceae from plant genus Cola, used as "Kola" and aphrodisiacs. Ricinodendron heudelotii (Euphorbiaceae) and Mondia whitei (Periplocaceae) are used as spices. Fruits of several tree species, such as Voacanga africana, $R$. heudelotii, Dacryodes edulis, Irvingia gabonensis, Mangifera indica, and Psidium guayava are sold to the local market. A few plant species, such as Gnetum africanum (Okok) (specifically in HGs) are also preserved for local consumption as a staple vegetable. About
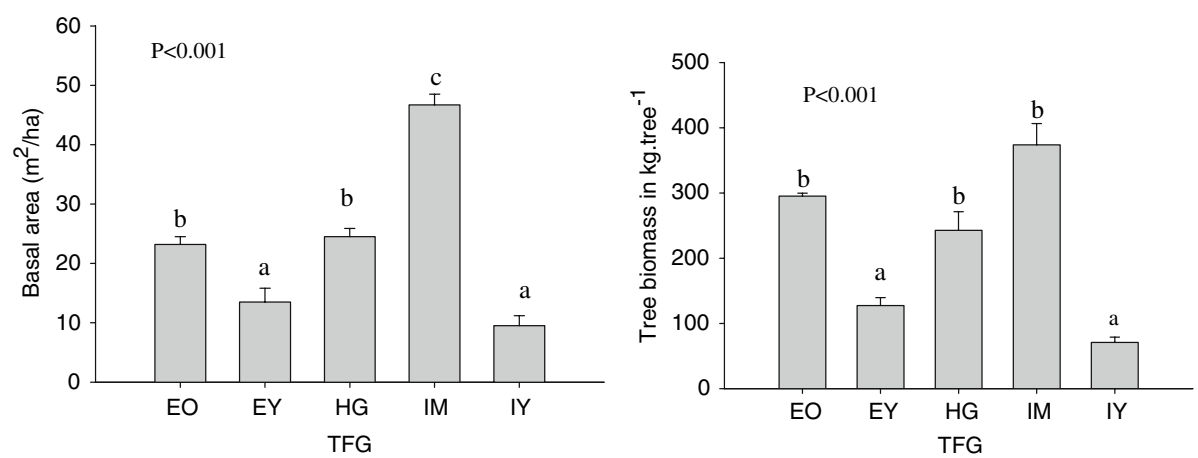

Fig. 4 Basal area $\left(\mathrm{m}^{2} / \mathrm{ha}\right)$ and tree biomass $(\mathrm{kg} / \mathrm{tree})$ of non-cocoa tree species in five TFG 
Table 4 Management index $(M I)$ from vegetation characteristics sampled in five cocoa forest gardens regions

\begin{tabular}{llllll}
\hline Vegetation variables & EO & EY & HG & IM & IY \\
\hline Tree species richness (no) & 0.48 & 0.69 & 0.57 & 0.64 & 0.75 \\
Herbaceous species richness (no) & 0.46 & 0.58 & 0.59 & 0.74 & 0.58 \\
Canopy cover (\%) & 0.12 & 0.27 & 0.16 & 0.24 & 0.56 \\
Herbaceous cover (\%) & 0.15 & 0.22 & 0.78 & 0.92 & 0.67 \\
Tree height (m) & 0.46 & 0.57 & 0.38 & 0.36 & 0.57 \\
Number of chupons & 0.95 & 0.89 & 0.77 & 0.93 & 0.97 \\
Cocoa tree density (tree/ha) & 0.38 & 0.41 & 0.20 & 0.46 & 0.45 \\
Total Management Index (MI) & & & & & \\
$\quad$ (A) & $2.98 \mathrm{a}$ & $3.63 \mathrm{~b}$ & $3.45 \mathrm{~b}$ & $4.29 \mathrm{c}$ & $4.55 \mathrm{c} * *$ \\
$\quad$ (B) & 1.67 & 2.33 & 2.48 & 2.90 & 3.13 \\
\hline
\end{tabular}

A high MI shows more intensive cocoa management. Letters show significant differences between regions based on Tukey's post hoc tests. $A$ MI using seven variables, $B$ MI using five variables

$* * p<0.01$

$60 \%$ of the bark of tree species in EO, $45 \%$ in EY, and $1 \%$ in IM, IY and HG, respectively, are peeled off for medicinal purposes.

\section{Management index (MI)}

The one-way ANOVA of the mean MI-values for each TFG revealed statistically significant differences among the five management systems $\left(F_{4,16}=7.94, d f=4, p<0.002\right)$ (Table 4). A Tukey's multiple comparison test indicated EO to be significantly different as compared to the other four systems. IY contained the least shaded cacao production sites while EO contained the most shaded; HG and EY were intermediate. Based on the MI we found that plant diversity and biomass of standing tree species significantly decreased with intensification.

\section{Discussion}

Floristic diversity and habitat description

Our study documents that management as practiced in traditional cocoa forest gardens in southern Cameroon following a gradient of intensification from extensive cocoa forest gardens with high floristic diversity to intensive ones strongly impacts plant diversity, plant biomass and to some extends carbon storage with possible negative consequences on biodiversity (Kotto-Same et al. 1997; Greenberg et al. 2000; Reitsma et al. 2001). Great differences in species richness and composition were evident among the five traditional cocoa forest gardens. In terms of plant species richness, we found a decreasing gradient of plant species numbers from extensive forest gardens to intensive ones. However, the species richness in cocoa forest home gardens (HG) exceeds all other numbers in the study area. What could be currently observed is the proliferation of pioneers or early secondary trees and poor conditions for the establishment of late secondary and climax species, 
resulting, consequently, in a lowering of tree diversity. This could be explained by the current management practices, specifically where undergrowth is cleared out twice annually in extensive systems and more in intensive ones. Such clearing are not selective, and all regenerating trees are eliminated and only a few arboreal plants happen to escape the cuttings. On the other hand, this could also be explained by the fact that before the cocoa crisis (Duguma et al. 2001), cocoa farmers were encouraged by the Societe de devéloppement du Cacao (SODECAO) to plant leguminous tree species such as the Albizia spp in cocoa plantations to enhance soil fertility. Ficus spp., C. pentandra, T. superba, and Milicia excelsa actively kept by the farmers, promote quick shading of the cocoa trees and are refuge for birds (Greenberg et al. 2000); beneficial insects (Philpott and Armbrecht 2006) and mammals (Rolim and Chiarello 2004). The young systems (EY and IY) present even higher densities of exotic tree species (Khaya senegalensis). On the other hand, the presence and conservation of secondary forests species in traditional cocoa forest gardens suggest that TFG could help to maintain biodiversity in landscapes where forest habitat is decreasing due to land-use pressure or may help to conserve endangered species (Zapfack et al. 2002; Schulze et al. 2004; Asare 2006; Bobo et al. 2006).

Herb species diversity was dominated by light-demanding herbs, specifically Acanthaceae, Commelinacea, Poaceae, and Asteraceae in patches and may function as indicators of the type of management.

The relatively low Jaccard Indices suggest a high $\beta$-diversity due to a high-species turnover. This is exemplified by the low proportion of shared species among the traditional cocoa forest gardens, specifically between EO and IY.

\section{Vegetation structure}

The average density of non-cocoa trees with $\mathrm{dbh} \geq 10 \mathrm{~cm}$ in traditional cocoa forest garden may be considered low (126 \pm 41.7 trees/ha) as compared to the less disturbed forest as reported by Zapfack et al. (2002). However, if compared to other cocoa systems such as the cabruca system in Brazil (Rolim and Chiarello 2004), this value is high. According to other studies (Steffan-Dewenter et al. 2007), planting of cocoa is economically viable at low tree density and thinning. Such practices may explain the type of landuse applied in intensive young systems (IY) resulting in poor plant diversity. However, farmers in these systems are concerned about the importance of tree as shade but lack appropriate technology in tree domestication or are not able to identify appropriate trees for shade.

The value of dbh in extensive TFGs were the lowest as compare to other TFGs and could be explained by a massive and selective logging during the cocoa crisis and the fall in market prices after 1992 (Duguma et al. 2001). Food diversification in HG (a combination of diverse fruit tree species in cocoa plantations), of similar age, has helped in preventing massive logging and plantations still possess timber tree species with significant dbh.

Basal area (BA) and biomass production

Basal area of timber species present in traditional cocoa forest gardens clearly decreased from young to old systems. The basal area of $46.7 \mathrm{~m}^{2} /$ ha from our mature systems, was higher than what was found by Zapfack et al. (2002) (i.e., $39.2 \mathrm{~m}^{2} / \mathrm{ha}$ ) and close to the 
value (i.e., $48.7 \mathrm{~m}^{2} / \mathrm{ha}$ ) recorded by Bobo et al. (2006) in primary forests in Southern Cameroon. It was also higher than the values $\left(11.9-20.5 \mathrm{~m}^{2} / \mathrm{ha}\right)$ obtained in cocoa plantations in Indonesia by Merijn et al. (2007) or elsewhere in the South province of Cameroon $\left(29.7-42.6 \mathrm{~m}^{2} / \mathrm{ha}\right)$ where some large trees $($ e.g. $\mathrm{dbh}=143 \mathrm{~cm})$ can still be found despite ancient selective logging activities (van Gemerden 2004). Our results suggest a good stock of remnant forest tree species such as T. superba, M. excelsa, Mansonia altissima, Entandrophragma cylindricum and planted multi-purpose trees such as oil palms E. guineensis, plum D. edulis and kola Cola acuminate in TFGs.

The large differences in above ground tree biomass among old and young TFGs are a good indication of the rate of intensification where farmers aimed at maximum cocoa productivity. Such practice may results in a significant loss of carbon (Kotto-Same et al. 1997; Steffan-Dewenter et al. 2007). According to Steffan-Dewenter et al. (2007) the removal of shade trees increased soil surface temperature by about $4{ }^{\circ} \mathrm{C}$ and reduced relative air humidity at $2 \mathrm{~m}$ above ground by about $12 \%$. These factors may have significant impact on the incidence of pests and diseases. We can also predict that the rate of biomass accumulation will probably decline as stands age because the dominant tree species are of economic importance and could be sold if there is a drastic drop of cocoa price at the international market. But TFGs will be profitable and sustainable if diversification of both crop and non-crop commodities such as non-timber forest products and fruit tree species is advocated (Zapfack et al. 2002; Bobo et al. 2006; Sonwa et al. 2007).

\section{Management index (MI) and vegetation variables}

The results of vegetative sampling and analysis of the MI (Table 4) clearly demonstrate that significant and measurable differences of MI can be quantified between different management systems of traditional cocoa forest gardens. Richness of non-cocoa tree species, herbaceous species, the average tree height, percentage of canopy and herbaceous cover were the principal variables explaining these differences. These results suggest the importance of TFGs as refuge areas for biodiversity, and subsequent structural diversity.

Three significantly different management systems could be identified among the traditional cocoa forest gardens studied: (1) The extensively managed cocoa forest gardens (EO), with the lowest MI and higher shade cover, as well as tree species richness; (2) the intermediate forest gardens (EY and HG) with intermediate MI; and (3) the intensively managed systems (IM and IY) with the highest MI and lowest shade cover and tree species diversity (Tables 1, 4). Such approach using a MI could be used for research and certification in the cocoa growing regions of the tropics, specifically in West and Central Africa where such indices do not exit. Traditional cocoa forest gardens in southern Cameroon are protected land-use systems where medicinal and edible plants, timber species and nontimber forest products are collected.

\section{Conclusion}

The results of this study demonstrates that management as practiced in traditional cocoa forest gardens in southern Cameroon following a gradient of intensification from extensive cocoa forest gardens with high floristic diversity to intensive ones strongly impacts plant diversity, plant biomass and to some extends carbon storage with possible negative consequences on biodiversity. However, domestication of forest species within the TFGs is 
one of the best options for satisfying certain social and economic needs and sustains smallholder production for increased social, economic, and environmental benefits. Such multi-resource land-use practices that create new landscape elements offer more scope for conservation of biodiversity, at both species-level and landscape-level, may help in regulating pests and diseases and allows for efficient adaptation to changing socioeconomic conditions. This study also highlights the importance of the MI for quantifying differences in the management of shade-grown cocoa. MI in relation to biodiversity, productivity and net income was assessed and we argue that MI could be used to standardize vegetation sampling protocols in certification and biodiversity evaluations and monitoring or to measure conservation progress and success. Such a certification scheme is well established for shade-grown coffee in Mesoamerica (Dietsch et al. 2004; Perfecto et al. 2005, Gordon et al. 2007) but does not exist for cocoa in West and Central Africa. Therefore, it would be very useful to combine the application of this MI with data on the faunal richness (birds, mammals, and beneficial insects) to assess the impact on pests and diseases as well as for the conservation of biodiversity based on the type of management.

Acknowledgment We thank the University of Goettingen (IPAG "International PhD Programme in Agricultural Sciences in Goettingen") for financial support. We are grateful to the staff of the laboratory of Entomology of IRAD, Nkolbisson (Yaoundé) for support during field work and farmers and their respective federations in Ngomedzap, Bakoa, Nkolombang, Talba and Kedia for their active collaboration during field work. We also tank our colleagues of the Cameroon National Herbarium (Yaoundé) for their help on plant identification and conservation.

\section{References}

Annon (2002) Rapport annuel du Ministère de l'Agriculture et du Développement Rural, pp 70

Asare R (2006) A review on cocoa agroforestry as a means for biodiversity conservation. Forest and Landscape Denmark, p 17

Bobo SK, Waltert M, Sainge MN, Njokagbor J, Fermon H, Mühlenberg M (2006) From forest to farmland: species richness patterns of trees and understorey plants along a gradient of forest conversion in Southwestern Cameroon. Biodivers Conserv 15:4097-4117

Carrière MS, Letourmy P, Mckey DB (2002) Effects of remnant trees in fallows on diversity and structure of forest regrowth in a slash-and-nurn agricultural system in southern Cameroon. J Trop Ecol 18:375-396

Colwell RK, Huston MA (1991) Conceptual framework and research issues for species diversity at the community level. In: Solbrig OT (ed) From genes to ecosystems: a research agenda for diversity. International Union of Biological Sciences, Paris, France

Degrande A, Duguma B (2000) Adoption potential of rotational hedgerow intercropping in the humid lowlands of Cameroon. AgREN 103:1-12

Dietsch T, Philpottt SM, Rice R, Greenberg R, Bichier P (2004) Conservation policy in coffee landscapes. Science 303:625

Duguma B, Gockowski J, Bakala J (2001) Smallholder cacao (Theobroma cacao Linn.) cultivation in agroforestry systems of West and Central Africa: challenges and opportunities. Agroforest Syst 51:177-188

Gordon C, Manson R, Sundberg J, Cruz Angón A (2007) Biodiversity, profitability, and vegetation structure in a Mexican coffe agroecosystem. Agric Ecosyst Environ 118:256-266

Greenberg R, Bichier P, Cruz Angón A (2000) The conservation value for birds of cacao plantations with diverse planted shade in Tabasca, Mexico. Anim Conserv 3:105-112

Guyer JI (1984) Family and farm in Southern Cameroon. African Research Studies No 15. Boston University African Studies Center, Boston

Kanmegne J, Smaling EMA, Brussaard L, Gansop-Kouomegne A, Boukong A (2006) Nutrient flows in smallholder production systems in the humid forest zone of southern Cameroon. Nutr Cycl Agroecosyst 76:233-248

Kotto-Same J, Woomer PL, Moukam A, Zapfack L (1997) Carbon dynamics in slash-and-burn agriculture and land use alternatives of the humid forest zone in Cameroon. Agric Ecosyst Environ 65:245-256 
Krebs CJ (1989) Ecological methodology. Harper and Row, New York, NY, USA

Laird SA, Leke Awung G, Lysinge RJ (2007) Cocoa farms in the Mount Cameroon region: biological and cultural diversity in local livelihoods. Biodivers Conserv 16:2401-2427

Lefroy EC, Hobbs RJ, O'Connor MH, Pate JS (1999) Agriculture as a mimic of natural ecosystems. Agroforest Syst 31:275-436

Magurran AE (1988) Ecological diversity and its measurement. Princeton University Press, Princeton, NJ, USA

Mas HA, Dietsch VT (2003) An index of management intensity for coffee agroecosystems to evaluate butterfly species richness. Ecol Appl 13:1491-1501

MCNeely JA, Schroth G (2006) Agroforestry and biodiversity conservation- traditional practices, present dynamics, and lessons for the future. Biodivers Conserv 15:549-554

Merijn MB, Steffan-Dewenter I, Tscharntke T (2007) The contribution of cacao agroforests to the conservation of lower canopy ant and beetle diversity in Indonesia. Biodivers Conserv 16:2429-2444

Michon G, De Foresta H (1997) Agroforest: pre-domestication of forest trees or true domestication of forest ecosystems? Neth J Agric Sci 45:451-462

Muschler R, Beer J (2001) Multistrata agroforest systems with perenial crops. Agroforest Syst 53:85-245

Perfecto I, Vandermeer JH, Bautista GL, Ibarra Nuñez G, Greenberg R, Bichier P, Langridge S (2004) Greater predation in shaded coffee farms: the role of resident neotropical birds. Ecology 85:2677-2681

Perfecto I, Vandermeer J, Mas A, Soto Pinto L (2005) Biodiversity, yield, and shade coffee certification. Ecol Econ 54:435-446

Philpott S, Armbrecht I (2006) Biodiversity in tropical agroforests and the ecological role of ants and ant diversity in predatory function. Ecol Entomol 31:369-377

Philpott SM, Perfecto I, Vandermeer J (2006) Effects of management intensity and season on arboreal ant diversity and abundance in coffee agroecosystems. Biodivers Conserv 15:139-155

Reitsma R, Parrish JD, McLarney W (2001) The role of cocoa plantations in maintaining forest avian diversity in southeastern Costa Rica. Agroforest Syst 53:185-193

Rolim GS, Chiarello GA (2004) Slow-death of Atlantic forest trees in cocoa agroforest in southern Brazil. Biodivers Conserv 13:2679-2694

Ruf F, Schroth G (2004) Chocolate forests and monocultures: a historical review of cocoa growing and its conflicting role in tropical deforestation and forest conservation. In: Schroth G, da Fonseca GAB, Harvey CA, Gascon C, Vasconcelos HL, Izac AMN (eds) Agroforestry and biodiversity conservation in tropical landscapes. Island Press, Washington, pp 107-134

Samways MJ (1984) Community structure of ants (Hymenoptera: Formicidae) in a series of habitats associated with citrus. J Appl Ecol 20:833-847

Schroth G, da Fonseca GAB, Harvey CA, Gascon C, Vasconcelos HL, Izac A-MN (2004) Agroforestry and biodiversity conservation in tropical landscapes. Island, Washington, DC

Schulze CH, Waltert M, Kessler PJA, Pitopang R, Shahabuddin, Veddeler D, Mühlenberg M, Gradstein RS, Leuschner C, Steffan-Dewenter I, Tscharntke T (2004) Biodiversity indicator groups of tropical landuse systems: comparing plants, birds, and insects. Ecol Appl 14:1321-1333

Shannon CE, Weaver W (1949) The mathematical theory of communication. University of Illinois Press, Urbana, IL, USA

Sonwa DJ, Weise SF, Tchatat M, Nkongmeneck BA, Adesina AA, Ndoye O, Gockwoski J (2001) The role of cocoa agroforests in rural and community forestry in southern Cameroon. RDFN Pap 25:1-10

Sonwa DJ, Nkongmeneck BA, Weise SF, Tchatat M, Adesina AA, Jansens MJJ (2007) Diversity of plants in cocoa agroforests in the humid forest zone of Southern Cameroon. Biodivers Conserv 16:2385-2400

SPSS Inc. (2004) Systat 11 for Windows. SPSS, Chicago

Steffan-Dewenter I, Kessler M, Barkmann J, Bos M, Buchori D, Erasmi S, Faust H, Gerold G, Glenk K, Gradstein RS, Guhardja E, Harteveld M, Hertel D, Höhn P, Kappas M, Köhler S, Leuschner C, Maertens M, Marggraf R, Migge-Kleian S, Mogea J, Pitopang R, Schaefer M, Schwarze S, Sporn GS, Steingrebe A, Tjitrosoedirdjo SS, Tjitrosoemito S, Twele A, Weber R, Woltmann L, Zeller M, Tscharntke T (2007) Tradeoffs between income, biodiversity, and ecosystem functioning during tropical rainforest conversion and agroforestry intensification. PNAS 104:4973-4978

van Gemerden BS (2004) Disturbance, diversity and distributions in Central African rain forest. Ph.D. thesis, Wageningen University, The Netherlands

Wiersum KF (2004) Forest gardens as an 'intermediate' land-use system in the nature-culture continuum: characteristics and future potential. Agroforest Syst 61:123-134

Zapfack L, Engwald S, Sonke B, Achoundong G, Birang M (2002) The impact of land conversion on plant biodiversity in the forest zone of Cameroon. Biodivers Conserv 11:2047-2061 